\title{
Effect of Uterine Artery Insulin Infusions on Umbilical Glucose Uptake in Sheep
}

\author{
CHARLES L. PAXSON, JR., FRANK H. MORRISS, JR., ${ }^{(28)}$ AND EUGENE W. ADCOCK III
}

Houston Perinatal Nutrition Laboratory, Departments of Pediatrics and of Obstetrics and Gynecology, Medical School, The University of Texas Health Science Center at Houston, Houston, Texas, USA

\begin{abstract}
Summary
Although glucose is an important fuel for fetal oxidative metabolism, regulation of its availability to the mammalian fetus is poorly understood. This study was performed to determine the effect of infusions of insulin into the uterine arterial circulation on umbilical uptake of glucose in chronically instrumented, unstressed sheep. Twenty-eight determinations of umbilical glucose uptake and diffusion clearance of glucose by the placenta were made in four ewes. Immediately following a control study during which saline was infused into the uterine artery, porcine regular insulin diluted in saline was infused at 0.05 to $8.1 \mathrm{mU} / \mathrm{min} \cdot \mathrm{kg}$ uterine weight for $20-30 \mathrm{~min}$ and the determinations were repeated. Subsequent studies were performed at the conclusion of additional infusions of insulin to a maximum of $21.6 \mathrm{mU} / \mathrm{min} \cdot \mathrm{kg}$.

There was a significant increase in umbilical glucose uptake during initial insulin infusions $(4.47 \pm 0.6 \mathrm{mg} / \mathrm{min} \cdot \mathrm{kg}$ fetus) compared to the control studies $(3.08 \pm 0.6 \mathrm{mg} / \mathrm{min} \cdot \mathrm{kg})$ associated with an increase in diffusion clearance $(13.8 \pm 1.9 \mathrm{ml} / \mathrm{min}$. $\mathrm{kg}$ fetus vs. $8.99 \pm 1.8 \mathrm{ml} / \mathrm{min} \cdot \mathrm{kg}$ ). When the total cumulative dose of exogenous insulin, $I_{t}$, was $162 \mathrm{mU} / \mathrm{kg}$ uterine weight or less, the umbilical uptake of glucose, $\dot{Q}$, may be expressed as a function of maternal arterial blood glucose concentration in milligrams per $\mathrm{dl},[\mathrm{A}]$, and of $\mathrm{I}_{\mathrm{t}}$.
\end{abstract}

\section{Speculation}

Exogenous insulin infused at physiologic rates into the ovine uterine artery increases the permeability of the placenta to glucose by increasing the initial rate of glucose transport by a carrier system into cells which comprise the placenta until insulin receptor sites are saturated.

Although glucose is an important fuel for fetal oxidative metabolism $(4,11)$, regulation of its availability to the mammalian fetus is poorly understood. Transfer of glucose across the placenta is by membrane-limited facilitated diffusion (26). An increase in maternal arterial blood glucose concentration is associated with an increase in umbilical uptake of glucose, but major changes in placental blood flow cause only small changes in umbilical glucose uptake.

Not all of the glucose taken up by the placenta from the maternal circulation diffuses into the umbilical circulation. In near term sheep, as much as $30 \%$ of uterine glucose uptake may be utilized to support the metabolism of the placenta and another $20 \%$ leaves the placenta as lactate in the uterine veins (21). In vitro experiments have yielded conflicting conclusions regarding the effect of insulin on the uptake of glucose, synthesis of glycogen, and production of lactate by human or sheep placenta $(3,7,14$, $24,25)$. However, Simmons et al. have shown that insulin administered in large doses to the unstressed sheep fetus in vivo increases diffusion clearance of glucose by the placenta and umbilical glucose uptake without apparent effect on placental glucose utilization (22).

The study reported herein was performed to determine the effect of infusions of insulin at physiologic rates into the uterine arterial circulation on umbilical uptake of glucose in chronically instrumented, unstressed sheep.

\section{MATERIALS AND METHODS}

Four Dorset and Western ewes at days 111-140 of gestation were fasted for $36 \mathrm{hr}$ before surgery. Under $5 \mathrm{mg} / \mathrm{kg}$ pentobarbital sedation and spinal anesthesia with $6 \mathrm{mg}$ Pontocaine in hyperbaric glucose, each ewe received polyvinyl catheters in a maternal femoral artery, a maternal uterine artery, a fetal pedal artery, and a fetal pedal vein as described previously $(4,12)$. The umbilical vein catheter was introduced directly into the umbilical vein 4-5 $\mathrm{cm}$ from the fetal abdominal wall, and the tip was advanced 1-2 $\mathrm{cm}$ within the abdominal wall. The catheter was glued in place in such a manner that umbilical vein blood flow continued.

After recovery from surgery the ewes were kept in stainless steel metabolic pens and allowed sweet feed (Omolene, Ralston Purina, St. Louis, MO) and water ad libitum. Catheters were flushed daily with heparin. Procaine penicillin, 600,000 U, and streptomycin, $0.5 \mathrm{~g}$, were administered for 3 postoperative days. Beginning on the fourth postoperative day each animal was studied until the catheters failed.

Each day a control study was performed at the conclusion of a 20-min infusion of normal saline into the uterine artery catheter $(0.2 \mathrm{ml} / \mathrm{min})$. Simultaneous blood samples were collected from the maternal femoral artery and fetal pedal artery and umbilical vein for glucose assay. Immediately following the control study, porcine regular insulin (Iletin, Eli Lilly and Company, Indianapolis, IN) diluted in normal saline to provide infusion rates of $0.05-8.1 \mathrm{mU} / \mathrm{min} \cdot \mathrm{kg}$ uterine wt and containing $2.5 \mathrm{ml} / \mathrm{dl}$ sheep plasma was infused at $0.2 \mathrm{ml} / \mathrm{min}$ for $20-30 \mathrm{~min}$ into the uterine artery catheter. Near the conclusion of the insulin infusion blood samples were collected for glucose assay. In three of the four animals, subsequent third and fourth studies were performed at the conclusion of additional insulin infusions, during which increasing incremental rates of insulin were infused to a maximum of $21.6 \mathrm{mU} / \mathrm{min} \cdot \mathrm{kg}$ uterine wt.

Umbilical blood flow was measured by the steady state antipyrine diffusion method (4). Whole blood glucose was determined by the glucose oxidase method (20). Umbilical glucose uptake, $\dot{\mathrm{Q}}$, was calculated by the Fick principle as the product of the umbilical blood flow times the umbilical venoarterial difference in whole blood glucose concentration. Diffusion clearance of glucose, C, was calculated as the quotient of the umbilical uptake of glucose divided by the glucose concentration difference between the maternal arterial blood and umbilical arterial blood, A - a (16): $C=\dot{Q} /(A-a)$. To allow for comparison between animals, diffusion clearance of glucose was expressed as a function of fetal weight. 
Table 1. Effect of increasing rates of uterine artery insulin infusion on transplacental glucose flux

\begin{tabular}{|c|c|c|c|c|c|c|}
\hline Ewe & $\begin{array}{c}\text { Gestational } \\
\text { age } \\
\text { (days) } \\
\end{array}$ & $\begin{array}{c}\text { Insulin infusion } \\
(\mathrm{mU} / \mathrm{min} \cdot \mathrm{kg} \text { uterus })\end{array}$ & $\begin{array}{c}\text { Total cumulative in- } \\
\text { sulin dose } \\
\text { (mU/kg uterus) }\end{array}$ & $\begin{array}{l}\text { Umbilical glucose up- } \\
\text { take } \\
\text { (mg/min } \cdot \mathrm{kg} \text { fetus) }\end{array}$ & $\begin{array}{l}\text { Diffusion clearance of } \\
\text { glucose by placenta } \\
\text { (ml/min } \cdot \mathrm{kg} \text { fetus) }\end{array}$ & $\begin{array}{l}\text { Maternal arte- } \\
\text { rial glucose } \\
(\mathrm{mg} / \mathrm{dl})\end{array}$ \\
\hline 1 & 123 & 0 & 0 & 3.16 & 13.62 & 44.94 \\
\hline \multirow[t]{4}{*}{2} & 137 & 0 & 0 & 5.74 & 14.95 & 63.57 \\
\hline & & 0.32 & 9.57 & 7.02 & 17.00 & 64.42 \\
\hline & & 0.67 & 29.72 & 12.86 & 33.30 & 58.87 \\
\hline & & 2.84 & 124.60 & 8.13 & 65.19 & 50.68 \\
\hline \multirow[t]{4}{*}{3} & 144 & 0 & 0 & 0.21 & 1.14 & 30.14 \\
\hline & & 0.19 & 5.61 & 1.50 & 8.73 & 24.80 \\
\hline & & 0.91 & 32.84 & 1.47 & 10.72 & 19.14 \\
\hline & & 1.72 & 84.55 & 1.12 & 8.29 & 17.17 \\
\hline \multirow[t]{11}{*}{4} & 115 & 0 & 0 & 2.95 & 7.41 & 58.62 \\
\hline & & 5.40 & 162.00 & 8.54 & 16.07 & 57.37 \\
\hline & & 10.80 & 378.00 & 1.51 & 3.95 & 45.49 \\
\hline & 117 & 0 & 0 & 5.58 & 15.18 & 68.17 \\
\hline & & 2.70 & 81.00 & 5.42 & 14.01 & 70.26 \\
\hline & & 5.40 & 243.00 & 2.39 & 6.35 & 69.29 \\
\hline & & 10.80 & 567.00 & 3.18 & 10.88 & 61.50 \\
\hline & 118 & 0 & 0 & 2.11 & 5.59 & 72.01 \\
\hline & & 8.10 & 243.00 & 4.05 & 8.62 & 85.42 \\
\hline & & 16.20 & 729.00 & 12.58 & 30.09 & 78.72 \\
\hline & & 21.60 & 1377.00 & 5.38 & 28.27 & 52.54 \\
\hline
\end{tabular}

Table 2. Comparison of transplacental glucose transport in sheep before (control) and during initial uterine arterial insulin infusion

\begin{tabular}{|c|c|c|}
\hline & Control & $\begin{array}{c}\text { Initial insulin } \\
\text { infusions }\end{array}$ \\
\hline No. of studies & 8 & 8 \\
\hline Maternal arterial glucose $(\mathrm{mg} / \mathrm{dl})$ & $55.8 \pm 4.8^{1}$ & $55.5 \pm 6.7$ \\
\hline Fetal arterial glucose (mg/dl) & $21.7 \pm 3.3$ & $20.9 \pm 4.0$ \\
\hline $\begin{array}{l}\text { Maternal-fetal arterial glucose dif- } \\
\text { ference }(\mathrm{mg} / \mathrm{dl})\end{array}$ & $34.1 \pm 3.7$ & $34.6 \pm 3.9$ \\
\hline $\begin{array}{l}\text { Umbilical venoarterial glucose } \\
\text { difference }(\mathrm{mg} / \mathrm{dl})\end{array}$ & $2.21 \pm 0.5$ & $3.22 \pm 0.4^{2}$ \\
\hline $\begin{array}{l}\text { Umbilical blood flow } \\
(\mathrm{ml} / \mathrm{min} \cdot \mathrm{kg})\end{array}$ & $134 \pm 8$ & $142 \pm 12$ \\
\hline $\begin{array}{l}\text { Diffusion clearance of glucose by } \\
\text { placenta }(\mathrm{ml} / \mathrm{min} \cdot \mathrm{kg})\end{array}$ & $8.99 \pm 1.8$ & $13.8 \pm 1.9^{2}$ \\
\hline $\begin{array}{l}\text { Umbilical glucose uptake } \\
(\mathrm{mg} / \mathrm{min} \cdot \mathrm{kg})\end{array}$ & $3.08 \pm 0.6$ & $4.47 \pm 0.6^{2}$ \\
\hline
\end{tabular}

'Mean \pm SEM.

${ }^{2} P<0.005$ (paired $t$-test, control $v s$. initial insulin infusion).

The significance of results was evaluated by parametric statistical tests (8). Paired $t$-test analysis was used to determine significant differences in mean values before and after glucose infusion. The method of least squares was employed to calculate regression equations, and the significance of the slope of each regression equation was determined the $F$-ratio test. Analysis of variance was used to determine the significance of the independent contributions of maternal arterial blood glucose concentration and total cumulative insulin dose infused to umbilical uptake of glucose.

\section{RESULTS}

Twenty-eight determinations of glucose diffusion clearance by the placenta and umbilical glucose uptake were made (Table 1).
When the total cumulative dose of exogenous insulin, $I_{t}$, was 162 $\mathrm{mU} / \mathrm{kg}$ uterine weight or less, the umbilical uptake of glucose in $\mathrm{mg} / \mathrm{min} \cdot \mathrm{kg}$ fetal weight, $\mathbf{Q}$, may be expressed as a function of maternal arterial blood glucose concentration in $\mathrm{mg} / \mathrm{dl},[\mathrm{A}]$, and of $I_{t}$ :

$$
\dot{\mathrm{Q}}=-1.34+0.087[\mathrm{~A}]+0.033 \mathrm{I}_{\mathrm{s}}
$$

( $\left.n=22 ; r=0.64 ; \mathrm{P}_{[\mathrm{A}]}<0.05, P_{\mathrm{I}_{\mathrm{t}}}<0.025, P_{\text {total }}<0.025\right)$. By analysis of variance the effects of $[A]$ on $Q$ and of $I_{t}$ on $Q$ are independent of any correlation between $[A]$ and $I_{t}$.

Exogenous insulin infusion to a maximum of $162 \mathrm{mU} / \mathrm{kg}$ increased umbilical glucose uptake by increasing the diffusion clearance of glucose by the placenta. Equation II expresses the diffusion clearance of glucose by the placenta in milliliters per $\mathrm{min} \cdot \mathrm{kg}$ fetal wt, $\mathrm{C}$, as a function of $\mathrm{I}_{\mathrm{t}}$ :

$$
C=5.30+1.76 I_{t}
$$

( $n=22 ; r=0.53 ; P<0.025 ; F$-ratio test). For the six studies in which the total cumulative exogenous insulin dose was greater than $162 \mathrm{mU} / \mathrm{kg}$, diffusion clearance of glucose by the placenta did not continue to increase consistently with increasing insulin doses.

A more detailed analysis of the effect of uterine artery insulin infusion on glucose flux to the ovine fetus is provided in Table 2 , which compares the eight initial regional insulin infusions to the preceding eight control studies. There was a significant increase in umbilical glucose uptake during insulin infusion compared to the control period with no significant change in maternal or fetal arterial blood glucose concentration, nor in the maternal-fetal arterial blood glucose concentration gradient, nor in the umbilical blood flow. Increased umbilical glucose uptake was the result of increased umbilical venoarterial glucose concentration difference during insulin infusions. The umbilical venoarterial concentration difference appears to have increased as the result of increased permeability of the placenta to glucose, as indicated by the in- 
creased diffusion clearance of glucose by the placenta. This analysis is valid for the eight paired studies even though the insulin infusion in ewe 4 on day 118 provided more than $162 \mathrm{mU} / \mathrm{kg}$. The analysis is unchanged when only those seven paired studies for which the total initial insulin dose was $162 \mathrm{mU} / \mathrm{kg}$ or less are considered.

\section{DISCUSSION}

The umbilical uptake of glucose can furnish approximately $50 \%$ of the fuel required for complete combustion of the umbilical oxygen uptake by the fetus of the well nourished ewe $(4,11)$. Umbilical uptakes of lactate produced by the placenta $(5,21)$, and of amino acids which may be subsequently catabolized can account for the balance of fuel required by the fetus of the well fed ewe $(10,13)$. However, when the ewe is fasted and/or becomes hypoglycemic, glucose is not the principal source of fuel for fetal energy metabolism. During prolonged maternal fasting, increased fetal urea production rates during the first 7 days suggest that fetal amino acid catabolism may provide as much as $80 \%$ of fetal oxidative substrate (23). Thus, the selection among and utilization of several potential substrates to support energy production is a dynamic fetal process which appears to depend in part on the availability of glucose acquired transplacentally.

This study demonstrates that the maternal insulin concentration in uterine arterial blood contributes to the regulation of umbilical glucose uptake. Ovine endogenous plasma insulin concentrations vary from approximately $20 \mu \mathrm{U} / \mathrm{ml}$ in the fasting state to approximately $80 \mu \mathrm{U} / \mathrm{ml}$ after feeding $(2,15)$. Calculated using an average red blood cell volume of $33 \%$ of whole blood volume and a uterine blood flow rate in late gestation of $200 \mathrm{ml} / \mathrm{min} \cdot \mathrm{kg}(19)$, the estimated rate of presentation of endogenous insulin to the ovine uterus is 2.5 to $10 \mathrm{mU} / \mathrm{min} \cdot \mathrm{kg}$. The infusions of exogenous insulin in the current study range from 0.05 to $21.6 \mathrm{mU} / \mathrm{min} \cdot \mathrm{kg}$.

Examination of the individual studies reveals that there is a wide range of values for control study umbilical glucose uptake which is related to the wide range of maternal arterial blood glucose values. Exogenous insulin infusions which augmented the rate of presentation of endogenous insulin by as little as $8 \%$ increased the umbilical glucose uptake appreciably in ewe 3 . The stepwise response to increasing exogenous insulin in ewe 3 and in ewe 4 on days 116,117 , and 118 appears to be blunted or overridden by decreasing blood glucose concentrations. It is likely that the infusion rate of exogenous insulin was greater than the capacity of the placenta to inactivate it $(9,17)$, resulting in a peripheral hypoglycemia. Ewe 4 responded variably on days 115 and 117. Very low infusion rates were provided on day 115. At autopsy the tip of the uterine artery infusion catheter was found just within a small side branch of the uterine artery distal to the side branch through which it had been inserted into the main uterine artery. Thus, the tip of the infusion catheter may have been similarly displaced from the main uterine artery on day 117 when no response was elicited from $2.70 \mathrm{mU} / \mathrm{min} \cdot \mathrm{kg}$ insulin infusion, which had evoked a response the preceding day.

The augmentation of umbilical glucose uptake by insulin in normoglycemic ewes is considerable, as may be shown by solving Equation I for no exogenous insulin and again for an insulin infusion of $162 \mathrm{mU} / \mathrm{kg}$, maintaining a constant maternal arterial glucose concentration of $55 \mathrm{mg} / \mathrm{dl}$. Umbilical glucose uptake increases 2.5 -fold from 3.45 to $8.80 \mathrm{mg} / \mathrm{min} \mathrm{kg}$ - fetal wt. Thus, although the ovine placenta is impermeable to insulin (1), it responds to increasing insulin concentrations in either the maternal or fetal blood which perfuses the placenta. The effect of exogenous insulin infusions within the physiologic range on umbilical glucose uptake is of the same magnitude as that evoked by a change in maternal arterial glucose concentration from a fasting $30 \mathrm{mg} / \mathrm{dl}$ to a postprandial $60 \mathrm{mg} / \mathrm{dl}$, for example, as calculated from Equation I.

The present study shows that infusions of insulin at physiologic rates into the uterine arterial circulation increase umbilical glucose uptake in a dose-dependent manner independent of maternal femoral artery blood glucose concentration. The assumption that maternal femoral arterial blood glucose concentration is equivalent to the glucose concentration in blood perfusing the cotyledons is supported by the report of Rosenfeld et al. (18) which demonstrated with a cast of a late pregnancy ovine uterine artery that myometrial, endometrial, and cotyledonary arterial vessels have separate points of departure from the common uterine artery. Thus, it is unlikely that glucose consumption by the endometrium and myometrium would reduce the glucose concentration in blood perfusing the cotyledons.

The present investigation did not examine the possibility that uterine artery insulin infusions alter the metabolic fate of glucose within the cells of the placenta. Simmons et al. (22) reported no effect of insulin administered to the ovine fetus on placental glucose utilization. The assumption that insulin administered via the maternal circulation likewise does not alter glucose metabolism by the placenta must be substantiated in subsequent investigations, for the calculated diffusion clearance of glucose by the placenta might be increased by a reduction in the processing of glucose taken up by the placenta to lactate. If the assumption drawn from the study of Simmons et al. is correct, then maternal insulin participates in the regulation of umbilical glucose uptake by directly affecting the transport of glucose across the cells of the placenta.

The mechanism by which insulin alters glucose transport by placental cells is unclear. However, studies conducted in brown fat cells suggest that the major effect of insulin on hexose transport processes is a marked enhancement of the apparent maximum velocity of transport rather than an effect on the diffusion constant (6). Our data are compatible with the hypothesis that insulin has a similar effect on the placenta: increasing doses of insulin enhance the initial rate of glucose transport by a carrier system into cells which comprise the placenta until the insulin receptor sites are saturated. The observed effect could be mediated by an increase in functional carrier site number on the maternal surface of the placenta or by an increase in carrier affinity or both.

\section{REFERENCES AND NOTES}

1. Alexander, D. P., Britton, H. G., Cohen, N. M., and Nixon, D. A.: The permeability of the sheep placenta to insulin: studies with the perfused placental preparation. Biol. Neonate, 21: 361 (1972).

2. Bassett, J. M.: Diurnal patterns of plasma insulin, growth hormone, corticosteroid, and metabolite concentrations in fed and fasted sheep. Aust. J. Biol. Sci., 27: 167 (1974).

3. Battaglia, F. C., Meschia, G., Blechner, J., and Barron, D. H.: Effect of insulin and poisons on glucose uptake of sheep and goat placenta. Amer. J. Physiol., 200: 64 (1961).

4. Boyd, R. D. H., Morriss, F. H., Meschia, G., Makowski, E. L., and Battaglia, F. C.: Growth of glucose and oxygen uptakes by fetuses of fed and starved ewes. Amer. J. Physiol., 225: 897 (1973).

5. Burd, L. I., Jones, M. D., Simmons, M. A., Makowski, E. L., Meschia, G., and Battaglia, F. C.: Placental production and foetal utilisation of lactate and pyruvate. Nature, 254: 710 (1975).

6. Czech, M. P., Lawrence, J. C., and Lynn, W. S.: Hexose transport in isolated brown fat cells: $\mathrm{A}$ model system for investigating insulin action on membrane transport. J. Biol. Chem., 249: 5421 (1974).

7. Demers, L. M., Gabbe, S. G., Villee, C. A., and Greep, R. O.: The effects of insulin on human placental glycogenesis. Endocrinology, 91 : 270 (1972).

8. Dixon, W. J., and Massey, F. J.: Introduction to Statistical Analysis, Ed. 3, (McGraw-Hill Book Company, New York, 1969).

9. Freinkel, N., and Goodner, C. J.: Carbohydrate metabolism in pregnancy. I. The metabolism of insulin by human placental tissue. J. Clin. Invest., 39: 116 (1960).

10. Gresham, E. L., James, E. J., Raye, J. R., Battaglia, F. C., Makowski, E. L., and Meschia, G.: Production and excretion of urea by the fetal lamb. Pediatrics, 50: 372 (1972)

11. James, E. J., Raye, J. R., Gresham, E. L., Makowski, E. L., Meschia, G., and Battaglia, F. C.: Fetal oxygen consumption, carbon dioxide production, and glucose uptake in a chronic sheep preparation. Pediatrics, 50: 361 (1972).

12. Killam, A. P., Rosenfeld, C. R., Battaglia, F. C., Makowski, E. L., and Meschia, G.: Effect of estrogens on the uterine blood flow of oophorectomized ewes. Amer. J. Obstet. Gynecol., 115: 1045 (1973).

13. Lemons, J. A., Adcock, E. W., Jones, M. D., Naughton, M. A., Meschia, G., and Battaglia, F. C.: Umbilical uptake of amino acids in the unstressed fetal lamb. J. Clin. Invest., 58: 1428 (1976).

14. Litonjua, A. D.: Studies on the glucose metabolism of human term placentas: Effects of insulin. Acta Med. Philippina, 3: 247 (1967). 
15. Manns, J. G., and Boda, J. M.: Insulin release by acetate, propionate, butyrate, and glucose in lambs and adult sheep. Amer. J. Physiol.. 212: 747 (1967).

16. Meschia, G., Battaglia, F. C., and Bruns, P. D.: Theoretical and experimental study of transplacental diffusion. J. Appl. Physiol., 22: 1171 (1967).

17. Posner, B. I.: Insulin metabolizing enzyme activities in human placental tissue Diabetes, 22: 552 (1973).

18. Rosenfeld, C. R., Morriss, F. H., Battaglia, F. C., Makowski, E. L., and Meschia G.: Effect of estradiol-17 $\beta$ on blood flow to reproductive and non-reproductive tissues in pregnant ewes. Amer. J. Obstet. Gynecol., 124: 618 (1976).

19. Rosenfeld, C. R., Morriss, F. H., Makowski, E. L., Meschia, G., and Battaglia, F. C.: Circulatory changes in the reproductive tissues of ewes during pregnancy. Gynecol. Invest., 5: 252 (1974).

20. Saifer, A., and Gerstenfeld, S.: The photometric microdetermination of blood glucose with glucose oxidase. J. Lab. Clin. Med., 51: 448 (1958)

21. Simmons, M. A., Burd, L. I., Lemons, J. A., Jones, M. D., Schreiner, R. L., Meschia, G., and Battaglia, F. C.: Placental utilization and conversion of glucose in vivo. Pediat. Res., 9: 279 (1975).

22. Simmons, M. A., Jones, M. D., Burd, L. I., Schreiner, R. L., Makowski, E. L.
Meschia, G., and Battaglia, F. C.: A direct effect of insulin upon placental glucose transport in vivo. Gynecol. Invest., 6: 31 (1975).

23. Simmons, M. A., Meschia, G., Makowski, E. L., and Battaglia, F. C.: Fetal metabolic response to maternal starvation. Pediat. Res., 8: 830 (1974).

24. Szabo, A. J., and Grimaldi, R. D.: The effect of insulin on glucose metabolism of the incubated human placenta. Amer. J. Obstet. Gynecol., 106: 75 (1970).

25. Villee, C. A.: The metabolism of human placenta in vitro. J. Biol. Chem., 205: 113 (1953).

26. Widdas, W. F.: Inability of diffusion to account for placental glucose transfer in the sheep and consideration of the kinetics of a possible carrier transfer. J. Physiol., 118: 23 (1952).

27. This research was supported by USPHS Research Fellowship I F22-HDO2224 0 I and by a Basil O'Connor Starter Research Grant from The National Foundation-March of Dimes.

28. Requests for reprints should be addressed to: F. H. Morriss, Jr., M.D., P. O. Box 20708 Texas Medical Center, Houston, TX 77025 (USA)

29. Received for publication August 15, 1977.

30. Accepted for publication November 2, 1977 